\title{
THE MILITARY BALANCE IN THE BALTIC SEA REGION - NOTES ON A DEFUNCT CONCEPT
}

\author{
Magnus Christiansson
}

$\mathrm{W}$

hen the organisers proposed the topic "The Military Balance in the Baltic Sea Region" for my lecture at the XIII Suomenlinna Seminar I was at first a little sceptical. What military balance? After all, the framing of a subject in those terms sounded like an anachronism since "military balance" has largely moved out from the political discourse. It reminded me of the Cold War, and it reminded me of a concept that many of my colleagues, for good reasons, are far from happy to use.

In fact, what happened after the Cold War was that most European politicians came to cultivate the idea that something fundamental had happened in world politics. Not only was there an end to the confrontation between Superpowers, but the cooperative relations between states in Western Europe was now seen as extendable also to Eastern Europe. A process of enlargement of both the EU and NATO commenced. This was a New Europe. The fundamental idea of security among states was formulated in the 1990 Charter of Paris for a New Europe: "Security is indivisible and the security of every participating State is inseperably linked to that of all others." 1 This is perhaps the clearest example of how power politics and spheres of influence were pushed aside in the discourse by treaty based cooperative politics. Furthermore, the idea of partnerships that blossomed in the 1990s was essentially a way to accommodate irregular security interests among the states in this New Europe.

Another driver of this development was the introduction of a term that successfully came to colonize the public discourse during the $1990 \mathrm{~s}$ - globalization. This is not an argument that relates to the ongoing debate about what this phenomenon is, but rather that it became a concept that every successful politician in the 1990s had to be familiar with. Globalization was both cause and effect. It was a promise for many and a horrible prospect for others. Sometimes an ideological gesture, sometimes a depiction.

The principal loser in globalization is the state. The economic significance of the state is questionable in times when the global financial systems, or

${ }^{1}$ CSCE (1990), p. 5. 
the digital herd as Thomas Friedman would say, could overrun every country. Related to this, some would claim closely related, was the regionnalization that in the European case was manifested by the accelerating intregration process of the EU. This, often called "Europeanization", was expressed by the efforts to coordinate a number of policy areas - foreign policy, monetary policy, environmental policy, migration policy, to name just a few - via different degrees of EU institutionalization.

Consequently, a state-centric public debate on security faded away in many European countries during the 1990s. Since traditional power politics was absent from the agenda attention turned to other problems. The focus of the Council of the Baltic Sea States (CBSS) is illustrative of this - environment, economic development, energy, education and culture. Not only is it common ground among its members, but it also reflects a diffusion of nontraditional security concerns. Security replaced strategy in the discourse.

This development was further accentuated after 9/11 and the US led Global War on Terrorism. Following the relative calm in the Balkans and the successful enlargement processes, an integrated Europe was now seen as normality and the major security concern was how much to support the remaining Superpower in its global endevours. The NATO countries of the Baltic Sea region met this debate directly during 2003 when the "transatlantic rift" put loyalties to test. The EU countries of the Baltic Sea region met this debate indirectly as the common security and defence policy was gradually designed. Power politics was associated with the US. Europe equalled "effective multilateralism".

But then something happened. Geopolitics and power politics came back into the discourse. Actually, there had always been scholars and politicians of the old school that never believed in a "New Europe". ${ }^{2}$ However distinguished, during the 1990s they had a hard time finding any significant place in the debate or in the corridors of political power. Many experts on Eastern Europe and Russia pointed out in the early 1990s that the democracy developed under the Yeltsin regime was indeed "stillborn" and only vaguely similar to Western democracy. ${ }^{3}$ But these experts, often critical to the "shock therapy" introduced by ingenuous Western economists, were marginalised and their warnings largely ignored. ${ }^{4}$ The conclusions of these early observers put a question mark after the rhetoric on a whole, free and integrated Europe that most politicians were using. Furthermore, this questionmark suggested that many of the policies associated with this "New Europe" were in fact dangerous and illusionary.

\footnotetext{
${ }^{2}$ See for example Mearsheimer (1990).

${ }^{3}$ See for example Gill \& Markwick (2000).

${ }^{4}$ Hedlund (2005).
} 
However, it took more than a decade for these thoughts to enter the mainstream of the debate. When Vladimir Putin came to power he seemed for many to belong to a new species in the post Cold War order: the elected autocrat. ${ }^{5}$ His agenda was gradually revealed, as he openly contested the principles of an open society, centralized means of power and installed vassalls from the old Soviet security apparatus. The military clash with Georgia in August 2008 was not a surprise for the experts, but proved to be an eye-opener for many in the Western European political circles. Over a sequence of a few days, it seemed for some, the Charter of Paris became an obsolete document from a previous era.

The British journalist Edward Lucas published an influencial book called The New Cold War: How the Kremlin Menaces both Russia and the West in which he argues that the West underestimates the danger that Russia poses for the world. ${ }^{6}$ His message echoed what many Eastern European countries had warned of and feared as junior partners in the trans-atlantic integration process. Shifting attention to issues on a wider security agenda and military transformation based on a notion of a "New Europe" seemed risky if Russia's behaviour challenged the very cornerstones of the European security order. For example, when the Estonian President Toomas Ilves openly asked the question "Can Berlin be defended?" broad concept of societal security, but the idea of territorial defence abandoned after the Cold War. Quite suddenly terms like "history", "power politics" and "spheres of influence" entered the public debate in some countries. Admittedly, this shift in the debate was not paradigmatic, but it definitely represented a new diversity in the European debate. ${ }^{8}$

So, after reconsidering the proposition to lecture on the military balance in the Baltic Sea region, I realized that there had emerged a political agenda that reintroduced many of the concepts from the Cold War in the debate, and that this indeed made it an interesting subject from many perspectives. The discourse had shifted and this, I would argue, is a challenge for the academic discipline of International Relations. A great deal of the development of academia after the Cold War has been dedicated to revising and criticizing the traditional perspectives that had proved to be both misleading and hollow. The comeback of these very concepts, as used by key actors in European politics, provides a good opportunity to revisit theory in the light of an agenda set by the actors we are to study. This is the purpose of this chapter.

\footnotetext{
${ }^{5}$ Zakaria (2003).

${ }^{6}$ Lucas (2008).

${ }^{7}$ Thielbeer (2008).

${ }^{8}$ Valasek (2008).
} 
The article will have four sections. In the first I will make my way into the conceptual jungle of the key concept of military balance provided to me by the organizers of the Suomenlinna Seminar. I will shift focus to military balancing. I will show in which ways it is possible to use this term, and what knowledge it could guide us to. In the second section I will describe the current military capabilities in the region. It will be a brief account that will represent fixed points that do not have theoretical or empirical importance in themselves. In the third section I will briefly describe and analyse the patterns of balancing behaviour among the states in the region using the theoretical toolbox introduced. Finally, I will discuss a few conclusions, both regarding military balancing in the Baltic Sea region as well as theory.

\section{What is military balance?}

As hinted above it is far from obvious that there is academic support for a new agenda of power politics in Europe. Some would argue that revisiting obsolete theory would be to surrender to or even indirectly support politics that create a more unstable and conflict prone Europe. To use military balance is in fact using discursive power that will marginalise cooperative politics, and in the end become a self-fulfilling prophesy.

However, as pointed out by Alexander Wendt, the notion that international politics is shaped by power relations is not reserved for any specific strand in International Relations. ${ }^{9}$ Applying it does not imply a specific agenda in itself. This means that the opposite argument could be made: after the clash in Georgia 2008 it would be to use discursive power to hide the importance of power politics in Europe. Instead, the theoretically important question is in what way power, including military power, matters. This is why the title of the lecture was wrongly formulated, not because it refers to a flawed (neo)realist heritage, but because it did not address the importance of military power in a meaningful way.

Balance, whether military or other, is a metaphor. As Richard Little points out, this aspect of metaphor must be taken seriously "because the source of the metaphor (balance) has the ability to transform the accepted meaning of the target of the concept (power)." ${ }^{10}$ Using it is an invitation to think of a scale where masses of military assests make the scale tip over to the advantage of the most powerful actor. Accordingly, when the International Institute for Strategic Studies (IISS) publishes their annual assessment of global military capabilities and defence economics, it is named The Military Bal-

\footnotetext{
${ }^{9}$ Wendt (1999), pp. 96-97.

${ }^{10}$ Little (2007), p. 19.
} 
ance. ${ }^{11}$ However, an assessment of the Armed Forces around the Baltic Sea could tell us something about proportions of matter. But this in itself it does not give any clue of the importance or impact of these proportions. An assessment could be used to find out patterns of defence spending and proportions of military equipment, but the label is misleading since it appears to provide an insight into which actors are more "heavy" than others in a specific region or conflict. To take but one contemporary example: one could argue that a country like Pakistan is just as important an actor in the Afghanistan conflict as the US, even if the latter ranks much higher on defence spending and military equipment.

One common way of describing this in theoretical terms is that power is a relation and not a resource. Whether defence spending of an actor results in this actor becoming "heavy" or not depends on the context. This relational approach to power underlines that any given power resource (like military resources) must be connected to a relation where power is to be exercised in order to assess its value. Some kind of framework of assumptions of which actor is trying to get which other actor to do what needs to be established, before the importance of military capabilities could be determined. Some scholars call this a "policy-contingency framework". Not to use such a framework would be, in the words of David Baldwin, to discuss what constitutes a good card hand without knowing which card game to play. ${ }^{12}$

However, I side with Olav Knudsen in that power as resource and power as relation do not necessarily rival each other. Power is on the one hand determined by the actor's own assessments where appearance of power becomes the guide to understanding relational action. At the same time the appearance interpreted by actors is the image of resources. ${ }^{13}$ There are two crucial elements in this reasoning: the first concerns the constant process of resource assessments performed by governments, and secondly the subjective element of the actors, based on interpretation and role identities. Or in other words, the power of a government is, to a large extent, what other governments think it is. ${ }^{14}$

According to Knudsen it is this process of estimation and assessment that constitutes a researchable phenomenon. This defines balancing of power: "a tendency or a pattern of behaviour of compensatory reaction to perceived power differentials." $"{ }^{15}$ It is important to underline that Knudsen makes a major point that (neo)realists, like Kenneth Waltz, have been too focused on military capabilities, since the process is ubiquitous. Thus, the

\footnotetext{
${ }^{11}$ IISS (2010).

${ }^{12}$ Baldwin (2006), pp. 179-180.

${ }^{13}$ Knudsen (2007), p. 11.

${ }^{14}$ Ibid., p. 26. This applies if governments are the actors.

${ }^{15}$ Ibid., p. 26.
} 
military balance is something distinct from the balance of power. An analyst can make a serious mistake by assuming that the study of military balancing does in fact give him a view of the balancing of power.

This angle provides the theoretical scope of this essay. In the following I will use the statistics of current patterns of defence spending and capabilities in the Baltic Sea region as the point of departure of this process of assessment. This part of the essay is simply a way to briefly sketch which (military) playing cards exist among the countries in the region. After that I will look closer at the different role conceptions, the (military) strategies that we find in the region. A meaningful use of military balance is thus a scholarly description of the cards while also covering the respective cardgames defined by the actors.

Finally this leaves us with a few limitations related to the scope of the study. From the chosen approach to military balance it is not entirely clear why there necessarily needs to be a regional limit. Indeed, as could be suspected, many factors and actors outside of the Baltic Sea region are likely to influence the strategies under study. International bodies like NATO are likely to have an impact and perhaps most importantly the policies of the US. It is quite likely that any process of balancing is not limited to the geography of the Baltic Sea. In other words: is there a Baltic Sea cardgame? This is the second reason why the title "The Military Balance in the Baltic Sea Region" is awkward - balancing behaviour in the region might not necessarily be limited by the region.

While the process of balancing could describe the patterns of state actors in the region, it could simultaneously provide us with empirical input to evaluate the status of the Baltic Sea region as a "level of analysis" in international politics. ${ }^{16}$ Theory could show us important dimensions in state behaviour, and state behavious could in turn show in what sense there is a regional dimension. These are the caveats when the lexical definition of "Baltic Sea region" will be defined as the states in the CBSS, not counting Iceland which does not have an armed force.

16 According to Buzan \& Waever (2003) the Balkans constitutes a sub-komplex. In principle, the Baltic Sea region could emerge as such a sub-complex. 


\section{Capabilities $^{17}$}

The 2009 ranking of the Baltic Sea region from the rough criteria of military spending in US\$ gives the following list:
1) Germany $46.5 \mathrm{bn}$
2) Russia $41.05 \mathrm{bn}$
3) Poland $8.63 \mathrm{bn}$
4) Norway $5.94 \mathrm{bn}$
5) Sweden $5.61 \mathrm{bn}$
6) Denmark $4.58 \mathrm{bn}$
7) Finland $4.21 \mathrm{bn}$
8) Lithuania $501 \mathrm{~m}$
9) Latvia $382 \mathrm{~m}$
10) Estonia $358 \mathrm{~m}$

\section{The Baltic states}

The three Baltic countries have the smallest set of military playing cards. All three have decreased their defence budgets in 2009. For example, Latvia cut down its defence budgets by $21 \%$. Lithuania is by far the greatest spender in US\$ with $501 \mathrm{~m}$. Estonia and Latvia are close together with $382 \mathrm{~m}$ and $358 \mathrm{~m}$ US $\$$ respectively. It is well worth noting that the total defence spending of the Baltic states (1.241bn US\$) is less than half of the second smallest spender in the region, Finland.

The composition of the Armed Forces of the Baltic states are all shaped by the process of defence transformation leading up to the NATO membership. The Armies have invested heavily in expeditionary participation in US led missions like Afghanistan. They are all dependent on reservists, and active components vary from ca. 1000 to 2500 troops in each country. The Navies have set up a joint unit BALTRON with bases in Liepeda, Riga, Ventspils, Tallinn, and Klaipeda. The total surface capabilities include a couple of frigates, 19 patrol vessels of various specifications, and some 11 mine warfare ships. The Air Forces lack any fighter component and are limited to transport, a few helicopters, and support capabilities.

\section{Denmark}

The defence budget in Denmark was increased from 4.46bn US\$ in 2008 to $4.58 \mathrm{bn}$ US\$ in 2009 . The plan is to gradually increase the budget until 2014. The style of the Armed Forces is that of an expiditionary corps with

\footnotetext{
${ }^{17}$ All figures are taken from IISS, International Institute for Strategic Studies (2010). I would like to thank Carina Solmirano of SIPRI for valuable advice on defence statistics.
} 
limited ability for self-reliance. Despite budget increases there will be cuts in the number of operational tanks, aircraft, and maritime response ships.

The core of the Army is a mechanized infantry brigade, supplemented by a training brigade. The training brigade consists of some 9 training units that supply the mechanized brigade with expeditionary units. Besides this there are individual independent battalions and units in reconnaissance, special forces, engineers, and air defence. The ambition of the Army is to field 2000 expeditionary troops.

The Navy has prioritized patrolling tasks and features some 49 ships for this purpose. Other than that there are 14 mine warfare ships and capabilities for flexible logistic support. There are two major bases at Korsøer and Fredrikshavn.

The Air Force is still depending largely on the F-16AM/F-16BM system. The political decision to purchase a replacement has been put on ice. The forces consist of 48 combat capable F-16s, and one squadron each of search and rescue and transport.

\section{Norway}

Norway has, perhaps a bit surprisingly, the largest defence budget among the Nordic countries. However, considering the near levelling of GDP figues when compared to neighboring country Sweden, it might seem more understandable. Norway spent 5.94bn US\$ in 2009 and that is a slight increase from the previous year.

The gist of the Army, based on conscription, is the Northern Brigade. One mechanized battalion in the brigade, (the Telemark battalion) is reserved for high readiness operations. Furthermore, assets include 1 special forces commando, 1 guards battalion, and 1 reconnaissance battalion.

The Navy has three major components: naval units, schools, and coast guard. The principal surface combatants are 3 frigates supported by 6 patrol ships and 6 mine warfare ships. The Navy has 6 Ula submarines. The facilities include bases at Bergen, Ramsund, and Trondenes. The coast guard, with its base in Sortland, has some 13 patrol craft.

The Air Force has 3 squadrons of F-16s. In November 2008 Norway decided to procure Joint Strike Fighter. Complementing the fighter capability are individual squadrons of maritime reconnaissance, search and rescue helicopters, electronic warfare, as well as transport. The total of combat capable aircraft is 52 . 


\section{Finland}

The neigboring country Finland has had a different development over the last years. Defence spending increased from 3.55bn US\$ in 2008 to $4.21 \mathrm{bn}$ US\$ in 2009. General conscription is maintained and thus the reserve forces still have an important function in the defence system. Thousands of reservists do refresher training every year.

Apart from the regimental size rapid reaction forces, the Army of Finland is based on mobilization of conscripts. The 4 military commands have a total strength of 3 Jaeger brigades, 2 air defence brigades, and 1 brigade each of armour, artillery, engineers, and signals. However, fully mobilized the Army has another 2 Jaeger brigades and some 6 infantry brigades, 29 infantry battalions, and no less than 170 companies in battle groups.

The Navy, with its headquarters in Turku, has maintained its focus on patrolling and coastal defence. It has 8 fast patrol craft and 19 mine warfare vessels, plus some 30 vessels for logistics and support. The amphibious forces are organized in a naval brigade. The Air Force is centered around the 3 fighter wings with F-18 Hornets. There is one fighter wing in each of the three air defence areas (West, East, and North) that Finland is divided into.

\section{Sweden}

The Swedish defence budgets have slightly decreased over the past few years and was $5.61 \mathrm{bn}$ US\$ in 2009 . We can note the relatively high level of arms procurement, as well as the total of $800 \mathrm{~m}$ US\$ that placed it as the world's $8^{\text {th }}$ country in global arms delivieries in 2008. The non-socialist coalition government has had the dual policy of not adjusting defence spending, while maintaining the existing regiments and flotillas. Domestically this has led to a dual critizism: for creating under-financed defence budgets, and for hampering the rationalization and transformation of the Armed Forces. General conscription was de facto abandoned in July 2010.

The aim for the development of the Army is 8 mechanized battalions, 2 artillery battalions, 3 air defence battalions, 3 engineer battalions and 2 logistics battalions. The Home Guard is to be organized into 60 multi purpose battalions. Recent development has created pressure to integrate armoured units as companies in the mechanised battalion structure.

The Navy organization has been restructured to include 2 surface flotillas, 1 surveillance battalion, 1 amphibious battalion, 1 submarine flotilla, and 1 logistics battalion. It has 4 submarines. The surface capabilities of the Navy are centered to the corvettes of Visby-class, with diverse operational quali- 
ties but with limited durability at sea. The Navy features some 22 vessels for mine warfare, but only one major cargo ship. The specialty of the amphibious battalion is combat in the archipelago ("brown waters").

The Swedish Air Force is dominated by the 4 squadrons with the fighterground attack plane JAS 39 Gripen. The original model with rather limited range is to be replaced with a long range version. Signals intelligence, airborne early warning, helicopters and air transport have one squadron each. Fighter control and air surveillance share one battalion, and there are 2 air base battalions.

\section{Poland}

Despite the initial plans for reductions of the Polish defence budget, resulting in the abandonment of the ambition to keep the goal of defence spending at $1.95 \%$ of GDP, the final decision came to an increase. The budget was 8.63bn US\$ in 2009.

The Army is centred around its mechanized corps (including the contribution to NATO's MNC NE Corps HQ). The corps consists of 1 armoured cavalry division, 3 mechanized divisions, 1 assault brigade, and 1 air cavalry brigade. The corps assets include 2 reconnaissance regiments, 2 artillery brigades, 2 engineer brigades and 1 engineer regiment, as well as chemical warfare components. The Polish have their 2 helicopter regiments as a part of the Army.

The Navy is divided into a surface combatant flotilla, a coastal defence flotilla, and a naval aviation brigade. The total of 8 major surface combatant ships include 3 frigates and 5 corvettes. It has 5 submarines. The mine warfare capability includes some 20 ships, and it has 8 light and medium landing ships. Naval bases are located in Kolobrzeg, Gdynia, Swinoujscie, Hel peninsula, and Gdynia-Babie-Doly.

The Air Force, with notable official individual flying hours for pilots at 160 to 200 hours per year, has 128 combat capable aircraft. There is an interesting mix between old Warsaw Pact systems like MiG-29 and US platforms like F-16. The Polish have organized them into 2 tactical wings, and have also a transport air wing, a special air transport wing, as well as 2 rocket air defence brigades.

\section{Germany}

The development of the German defence budget over the last years is strongly linked to the financial crisis of 2008. However, unlike the Baltic states, the defence sector has been the target of the government's stimulus 
package. Thus, the Grand Coalition government raised the 2009 budget from 41.6bn US\$ in 2006 to 46.5bn US\$ in 2009. During 2010 the German debate has featured suggestions for substantial capability cuts as well as a highly controversial abandonment of conscription.

The German transformation of the Armed Forces will create units in three categories: response forces, stabilization forces and support forces. The Army consists of 12 brigades in total, commanded by 5 headquarters, of which 3 are deployable. The composition features an armoured division, a mechanized division, a special operations division, and an air mobile division.

The Navy has merged its Type Commands into two mixed flotillas: one with submarines, mine countermeasures, patrol boats, as well as special forces, and one with frigates and auxilliary squadrons. It has some 18 surface combatants, 37 mine countermeasure vessels, 12 submarines, 3 amphibious craft. The bases include Olpenitz, Wilhelmshaven, Glücksburg, Warnemünde, Eckenförde, and Kiel.

The air component consists of three main systems: Eurofighter, Phantom, and Tornado. The organization no longer has any Warsaw Pact systems. Germany has 303 combat capable aircraft. The Air Force also features a substantial transport command with 96 aircraft, and 83 helicopters.

\section{Russia}

The Russian defence system is perhaps the most difficult one to substantiate without major errors. A substantial part of the budget is classified. The Russian Armed Forces have been undergoing different forms of reform for more than one decade. This is a process that is continuing. One estimate of defence expenditures approximates spending to $41.05 \mathrm{bn}$ US\$ in 2009, a slight increase on the year before.

Russia possesses a military playing card that none of the other countries in the region have: nuclear weapons. The Strategic Deterrent Forces, with personnel from the Navy and the Air Force, include 14 ballistic-missile submarines, 3 rocket armies, and 2 heavy bomber divisions. The doctrine still places great emphasis on these capabilities.

The Army consists of some 395,000 personnel, this is a figure that most likely will decrease over the coming years. It is organised into 6 military districts. The Leningrad Military Disctrict has 2 motor rifle brigades, a Spetsnaz brigade, 1 airborne division, plus various support elements. 
The Navy consists of 142,000 personnel. It is organised into 4 major Fleet organisations: Northern Fleet, Pacific Fleet, Baltic Fleet, and Black Fleet (not counting the Caspian Sea Flotilla). The Baltic Fleet, with bases in Kronstadt and Baltiysk, has 2 submarines, 5 surface combatants, 22 patrol craft, and 11 mine warfare vessels. There is a substantial air component attached: fighters, ground attack, and helicopters. There is also 1 naval infantry brigade.

The Air Force consists of 160,000 personnel. The organisation will see significant restructuring over the coming years. The main components are the $37^{\text {th }}$ Air Army with 2 heavy bomber divisions, 21 regiments of tactical bombers, 24 regiments of fighters, and 20 regiments of attack helicopters.

\section{Summary}

Comparison of military capablities of the states on the Baltic Sea Region is presented in the summary table 1 underneath.

\section{BALT DEN NOR FIN SWE POL GER RUS}

$\begin{array}{lllllllll}\text { Reg. Army brigades } & 3 & 2 & 2 & 4 & 2 & 15 & 12 & 58 \\ \text { Surface combatants } & 2 & 0 & 3 & 0 & 5 & 8 & 18 & 42 \\ \text { Amph. landing craft } & 0 & 0 & 20 & 73 & 185 & 8 & 3 & 27 \\ \text { Combat capable air. } & 0 & 48 & 52 & 63 & 165 & 128 & 303 & 1859\end{array}$

Table 1: Summary of military capabilities on the Baltic Sea region

The summary table is a highly rhapsodic way of portraying the "military costumes" in the Baltic Sea region - not counting nuclear capabilities, mobilization units and many other relevant capabilities. Strategists should object to its value, not just because its highly contestable value in relation to the notion of power, but to the fact that it says very little about the qualitative dimension. Nevertheless, despite these objections it has some value since it hints at the bulk of military capabilities in the region. In the following we will study the impact and role of military capabilities in the behaviour of actors around the Baltic Sea.

\section{Balancing behaviour}

Firstly, let us not assume that we should connect state behaviour to capabilities in themselves, but rather that identities, perceptions of history, and strategic culture could be just as useful for understanding these patterns. Hence, we should not group countries into "small", "medium" and "major" state categories after looking at the bulk of military hardware. Regardless of causal mechanism for behaviour: the point about the following section is 
to note the role of military balancing as discussed earlier. Very roughly we could then group the countries in the Baltic Sea region into three different types of strategic behaviour: assurance, avoidance and self-realization.

\section{Strategies of assurance}

The typical charateristic for strategies of assurance is that reliance on foreign powers is relatively uncontroversial. Accordingly, the foreign policy behaviour of the US is relatively uncontroversial and there is often a great understanding for its pivotal role as strategic actor. In practice this means that NATO is the primary international security arena. The Baltic States, Denmark, Norway, and Poland all fall into this category.

One striking pattern of balancing is that all the proponents of a revitalisation of Article 5 within NATO could be found in this group of European countries. With the exception of Denmark, the other states have openly declared that the alliance should strengthen and uphold a credible deterrence in the region. ${ }^{18}$

Perhaps the clearest example of balancing behaviour seems to be the strong foreign policy signals from the Baltic States after the Georgian crisis in 2008. However, this behaviour is more complex than one might assume. The Baltic States were hit by the financial crisis in 2008 and, as we have seen, their actual military capabilities were down during 2009. One could say that Lehman Brothers 2008 was just as important strategic factor as Georgia 2008.

Furthermore, as we noted above, the Baltic countries lack air force capabilities. This is definately a "perceived power differential" that has led to intense policy initiatives. Not least since these countries decided to abstain from developing their own capabilities in the run up to membership in NATO. In this sense they all have rather extreme strategies of assurance. Note that Estonia has, apart from the symbolic representation in the Nordic Battle Group, some 150 men in Helmand province. Perhaps the signals about increased attention from the US, including the concept of "extended deterrence", will be sufficient for the needs of the Baltic states. The "wise man's group" report by former Latvian prime- and foreign minister Valdis Birkavs and former Danish defence minister Søren Gade, as well as the recent visit of US Chief of Naval Operations to the region, might be seen as further signs of increased attention. ${ }^{19}$

\footnotetext{
18 Jonson (2010).

${ }^{19}$ NB8 (2010) and US Navy (2010) CNO visits Norway, Sweden [http://www.navy.mil/search/display.asp?story_id=55522].
} 
Though Denmark shares many of the traits of a rather pronounced strategy of assurance, it is difficult to notice any patterns of balancing behaviour. Quite contrary, capability differentials in the region are generally dismissed as a strategic factor. One telling fact is the almost total absence of naval capabilities adjusted to a Baltic agenda. The role of strategic assurance is firstly that it will give greater influence for a country with only 5.5 million inhabitants. It is in this light we should regard the relatively high casualty figures and the active role taken in Afghanistan and Iraq. Rather than "balancing" it is the unexpected costs in Afghanistan that is the major reason for the increased defence budget.

Norway has shifted its strategic attention to the North. Not only are some key military facilities relocated to signal this, but the strategic debate has pointed out the potentials of the Barents region as a major interest. However, the recent settlement with Russia on border disputes in this area has lowered the potential for any military confrontations considerably. Nevertheless, Norway has decided to purchase Joint Strike Fighter which fits with a strategy of assurance.

Poland has, like Denmark and the Baltic states, invested heavily in the transatlantic link. It has had nearly 2000 troops as a contribution to ISAF. However, the country is also one of the "defencists" in NATO. Concerns over energy security has been on the top of the strategic agenda, but following the tragic plane crash incident in the Spring of 2010, that killed Lech Kaczynski and a great part of the military leadership, there have been quite healthy relations between Poland and Russia.

\section{Strategies of avoidance}

The defining trait of a strategy of avoidance is a traditional military self reliance. It is also marked with an ambigious view of the US. Not surprisingly the EU constitutes the primary security arena. In the Baltic Sea region Sweden and Finland pursue this strategy.

However, there are some important differences between the two countries. They have made different choices between paths leading to a flexible operations defence or the maintance of territorial defence. Sweden stumbles down the former path while Finland clings on to the latter.

In general Finland has kept its focus on territorial tasks for the Armed Forces. After the clash in Georgia in 2008, Sweden reintroduced a national perspective in its defence planning, reintroduced regional commands, national objectives and national exercises. The reactions in Finland rather confirmed the chosen path and reinforced existing arrangements. It is fair to say that the country, with its readiness brigades, mechanized battle 
groups, helicopter battalion, regional battlegroups, as well as fighter squadrons, maintains a deterrence force. In terms of balancing behaviour it is clear that there were different reactions to Georgia: Finland raised its defence budget by $16 \%^{20}$, while Sweden prolonged the analysis for its Defence Bill without any financial commitments.

However, there are also similarities. Both countries have great hopes for Nordic defence and security cooperation. Though this process arguably started in 2007 as a Swedish-Norwegian initiative, Finland soon became a part of it. A relatively successful project, at least from an organizational perspective, was the setting up of the Nordic Battle Group. However, this process was initiated before the clash in Georgia and was not motivated by balancing concerns.

More broadly, though, the whole project of Nordic defence and security cooperation is motivated by a concern for sustaining military capabilities over longer time. This includes both expeditionary as well as national systems. Connected with this is a gradual discursive move into solidarity, also in military terms, among the actors in the region. It is difficult not to regard this development without its implications for territorial integrity in the regional context. Regardless of the driving forces behind this declaratory solidarity, it certainly has created a discussion about its meaning for the Baltic states. Hence, the process behind the suggestions for declared solidarity in the EU-Nordic context might not have been an act of balancing, but it could produce patterns of balancing behaviour. If clarified, it becomes something to potentially act upon.

The historical track record of solidarity in Sweden and Finland, in military terms, is rather meagre. Sweden pursued a policy of condemning the Soviet aggression in the Winter War 1939 - but without officially sending any troops in support for Finland. After the fall of the Berlin Wall it was Denmark that first offered bilateral defence agreements with the Baltic States. Finland was the first to offer weapons, while Sweden waited to provide weapons until the Soviet troops had returned home. Accordingly, there has not been any official assurance from Sweden to provide military assistance in a case of turbulence in the Baltic States.

All together it is difficult to see the development as purely acts of military balancing. Though the Baltic Sea region is important for Sweden and Finland, it is not clear in what ways the military capability development is connected with this. In many respects Sweden has had a "deterritorialized" policy, and for Finland the policy has not changed too much, even if the

${ }^{20}$ IISS (2010), p. 117. 
compensatory tendencies at least could be registered after the Russian actions in Georgia.

\section{Strategies of self-realization}

A strategy of self-realization is a method of realizing the inherent possibilities as perceived by a state. In essence: to become something more. Perhaps the opposite strategy could be defined as bandwagoning; a strategy that is essentially an act of submission. The two countries in the region that pursue this strategy are Germany and Russia.

The post-Cold War order has put these two states in juxtaposition. This gradually became evident as there was no general EU mechanism for interaction with Russia. No doubt the bilateral dialogue is more important for the two. But this has also created a few question marks regarding the intentions and role of these countries in the Baltic Sea region.

Perhaps the strongest strategic bond between Russia and Germany is the energy issue. While Russia has an incentive to sell its gas and other energy products, Germany is dependent on deliveries of these products. Russia is Germany's leading energy supplier. ${ }^{21}$ Germany has helped in exploiting gas fields in Russia, and the Nord Stream pipeline in the Baltic Sea is perhaps the most strategic joint venture up to date. One could of course speculate about the degree of interdependency, but it would be misleading not to note this common strategic interest.

However, there are also diplomatic signs of common strategic interests. Both countries ended up on the same side against the Americans in the events leading up to the 2003 Iraq war. On 4-5 June 2010 Russian President Medvedev met with Chancellor Merkel at Schloss Meseberg in Germany. The memorandum ${ }^{22}$ that followed the summit is interesting from many perspectives. It suggests an EU-Russian Political and Security Committee on ministerial level, for diplomatic consultations. However, it also suggests the establishing of "ground rules for joint EU-Russia civil/military crisis management operations." 23 An area for practical cooperation is defined as Transnistria where "EU-Russia engagement [...] would guarantee a smooth transition of the present situation to a final stage." 24 It seems that the German course set to re-engage the Russians in a constructive dialogue that concerns the frozen conflict in Moldova, but it is not without risks. The

21 German Foreign Ministry (2010) [http://www.aktion-europa.diplo.de/diplo/ en/Aussenpolitik/RegionaleSchwerpunkte/Russland/Russland-Wirtschaft-Energie.html].

${ }^{22}$ German-Russian Foreign Ministries (2010).

${ }^{23}$ Ibid.

${ }^{24}$ Ibid. 
signal of Germany and Russia making "suggestions" about the old Bessarabian question has many bad historical connotations.

The strategic juxataposition is not the only trend. There are also many signs that Germany policy has been shifting. The Germany that once, in the words of Chancellor Kohl, was addicted to American power, has slowly drifted on to a new course. Germany is one of five NATO countries that have demanded withdrawal of US nuclear bombs from its soil. This is not only a German signal for disarmament and confidence building, since it is not coordinated with American interests. This does not necessarily raze the US pillar in its security policy, but it certainly weakens it.

Furthermore, there is also a German domestic factor to take into account. In late May 2010 President Horst Koehler resigned after a row over remarks where he linked the use of military forces to national interests. While it says something about the country's pacifist strategic culture it is also an interesting insight into the discourse of leading politicians. On the road to the upcoming military reform the almost sacred structure of conscripition has been questioned. Not only does interaction shape a change of German policy, so is the domestic dimension.

In Russia, the general tendency since the late 1990s has been to give priority to rearmament. The planned procurement of Mistral class amphibious landing craft, for use in the Baltic setting, complicates things even further. A French-Russian bargain would put the Alliance coherence into question, since the Americans have been lukewarm and the Baltic states outright alarmistic.

Apparently, one of the lessons drawn from the clash in Georgia in 2008 was that the Russians won most because of vast superiority. This, and other factors, has triggered a response for an ambitious military reform that is yet only in its initial stages. Also, the simulated nuclear assaults and the presidential authority to deploy forces outside the country without parliamentary permission, has created international attention. However, one must also consider its domestic background for the Medvedev-Putin duovirate and not only its function as balancing behaviour.

\section{Conclusions}

As we have seen there are many patterns in the region that fit with the notion of balancing behaviour. However, it is also clear that many of these patterns must also be attributed to other factors. It is striking how a purely military focus could lead to wrong conclusions. In that sense, military bal- 
ance cannot, and should not be used as the sole explanatory theory of international relations.

A second conclusion regarding the balancing behaviour is that it is not only thematically too narrow, but that it is ill-suited for regional studies. It just seems to be impossible to understand and explain the foreign policy behaviour of any of the countries in the region from purely looking at regional factors. Just to mention a few of these: the relationship to the US is a key factor, but also processes that take place within the EU and NATO. The theoretical implications are noteworthy. As hinted in studies of Nordic regional cooperation there always seems to be processes from the outside that set in when regional factors become too independent. ${ }^{25}$

However, it is equally clear that a study of military capabilities and the courses of action in the Baltic Sea region is also fruitful. We have seen that the Baltic States, with small capabilities and a pronounced strategy of assurance, act very much in line with balancing theory. Finland is an example of a country with compensatory behaviour, while pursuing a strategy of avoidance. Countries like Denmark, Norway, and Poland have all trusted a strategy of assurance, but have not had a clear pattern of balancing. Sweden is perhaps the best example of a country that is "post security" to use the words of Pertti Joenniemi. ${ }^{26}$ Sweden has neither balanced, nor sought security guarantees. The aforementioned trends are compiled in table 2 underneath.

ASSURANCE

\begin{tabular}{cc|c|c|}
\multicolumn{1}{c}{ BALANCING } & \multicolumn{2}{c}{ Yes } & \multicolumn{2}{c}{ No } \\
\cline { 3 - 4 } & No & BALTIC STATES & FINLAND \\
\cline { 3 - 4 } & DENMARK, NoRWAY, PolAND & SWEDEN \\
\cline { 3 - 4 } & &
\end{tabular}

Table 2: Balancing and assurance for countries with small or medium capabilities in the Baltic Sea Region.

The policy conclusions, or speculations, are also of interest. The policies of assurance and avoidance are both dependent on faith in multilateral solutions and international regimes. Thus, no state expects to deal with major security problems in the region alone. But this also means that there will be major challenges in a situation when these institutions and regimes cannot function or provide functioning tools. Such "bad case scenarios" could be an interesting test of the value of any security policy pursued. The question is then: which course is best suited for stormy weathers - balancing with

\footnotetext{
${ }^{25}$ Sundelius (1982) and Ring (2009).

${ }^{26}$ Joenniemi (2007).
} 
assurance (the Baltic States), balancing without assurance (Finland), assurance without balancing (Denmark, Norway, and Poland) or a policy of post security (Sweden)?

\section{Bibliography}

Baldwin, David A. (2006) "Power and International Relations" in Carlsnaes, Walter, Risse, Thomas \& Simmons, Beth A. Handbook of International Relations, London: Sage.

Buzan, Barry \& Waever, Ole (2003) Regions and Powers. The Structure of International Security, Cambridge: Cambridge University Press.

Commission on Security and Cooperation in Europe (1990) Charter of Paris for a New Europe.

[http://www.osce.org/documents/mcs/1990/11/4045_en.pdf]

German Foreign Ministry (2010), [http://www.aktioneuropa.diplo.de/diplo/en/Aussenpolitik/RegionaleSchwerpunkte/Russland/ Russland-Wirtschaft-Energie.html]

German and Russian Foreign Ministries (2010) Meseberg memorandum. [http://www.russianmission.eu/sites/default/files/user/files/2010-06-05meseberg-memorandum.pdf]

Gill, Graeme \& Markwick, Roger D. (2000) Russia's Stillborn Democracy? From Gorbatchev to Yeltsin, Oxford: Oxford University Press.

Hedlund, Stefan (2005) Russian Path Dependence, Oxon \& New York: Routledge.

International Institute for Strategic Studies (2010) The Military Balance 2010. The global assessment of global military capabilities and defence economics, London: Routledge.

Joenniemi, Pertti (2007) “Towards a European Union of post-security?", Cooperation and conflict, vol. 42.

Jonson, Pål (2010) "The debate about Article 5 and its credibility. What is it all about?", NATO Defense College Research Paper, no. 58 May.

Knudsen, Olav F. (ed.) (2007) Security Strategies, Power Disparity and Identity. The Baltic Sea Region, Aldershot \& Burlingston: Ashgate. 
Little, Richard (2007) The Balance of Power in International Relations. Metaphors, Myths and Models, Cambridge: Cambridge University Press.

Lucas, Edward (2008) The New Cold War. How the Kremlin Menaces both Russia and the West, London: Bloomsbury Publishing.

Mearsheimer, John (1990) "Back to the Future. Instability in Europe after the Cold War", International Security, no. 1, pp. 5-56.

NB8 (2010) NB8 wise men report. August 2010, [http://www.utanrikisraduneyti.is/media/Skyrslur/NB8-Wise-Men-Report.pdf]

Ring, Stefan (red.) (2009) Nordisk försvarstransformation Militärstrategisk utveckling i Danmark, Finland och Norge efter det kalla kriget (FM Litt 922:2802) Stockholm: FHS Ö166/2008:40.

Sundelius, Bengt (ed.) (1982) Foreign Policies of Northern Europe, Boulder: Westview Press.

Thielbeer, Sigfried (2008) "Baltische Befürchtungen: Das Verschenkte Georgien”, Frankfurter Allgemine Zeitung, 26 August.

US Navy (2010) CNO Visits Norway, Sweden, [http://www.navy.mil/search/display.asp?story_id=55522]

Valacek, Tomas (2008) "What does the War in Georgia mean for EU foreign policy?", Centre for European Reform briefing note, August.

Wendt, Alexander (1999) Social Theory of International Politics, Cambridge: Cambridge University Press.

Zakaria, Fareed (2003) The Future of Freedom: Illiberal democracies of home and abroad, New York: Barnes \& Noble. 